\title{
Pediococcus spp.-fermented chicken meat for dogs
}

\author{
Eunchae Lee ${ }^{1}$, Ki-Taek Nam²${ }^{2}$ Kyung-Woo Lee ${ }^{1}$ and Sang-Rak Lee ${ }^{1 *}$ \\ ${ }^{1}$ Department of Animal Science and Technology, Konkuk University, Seoul 05029, Korea \\ ${ }^{2}$ Department of Animal Life and Environment Science, Hankyong National University, Anseong 17579, \\ Korea
}

\section{Abstract}

An experiment was conducted to evaluate Pediococcus spp.-fermented chicken meat as a snack for dogs. The fermented or non-fermented snacks used in this study were prepared through the following process; meat mixtures containing 52.8\% MDCM, 35.2\% chicken breast meat (CBM) and $9.7 \%$ corn starch were inoculated with or without Pediococcus spp., incubated at $37^{\circ} \mathrm{C}$ for $24 \mathrm{~h}$ and then sterilized at $121^{\circ} \mathrm{C}$ for $20 \mathrm{~min}$. During the $24-\mathrm{h}$ fermentation, the $\mathrm{pH}$ of fermented chicken snack dropped rapidly with concomitant increase in number of lactic acid bacteria. The nutritional composition was not altered by fermentation. In vitro pepsin nitrogen digestibility was higher $(p<0.05)$ in the fermented snack compared with the non-fermented snack. Upon storage at room temperature for 14 days, bacteria grew slowly in fermented vs. non-fermented snack samples. In a palatability trial, dogs preferred non-fermented over fermented snack food. In 12-d-long feeding trial, fecal ammonia content was lowered, but fecal lactic acid content was increased in dogs fed the fermented vs. non-fermented snack food. Our study shows that the fermented MDCM-based snack exhibited good preservability upon storage, and improved in vitro nitrogen digestibility and fecal characteristics in dogs.

Keywords: Chicken meat snack, Dog, Fermentation, Mechanically deboned chicken meat, Palatability creativecommons.org/licenses/bync/4.0/) which permits unrestricted non-commercial use, distribution, and reproduction in any medium, provided the original work is properly cited.

ORCID

Eunchae Lee

https://orcid.org/0000-0003-0143-4022 Ki-Taek Nam

https://orcid.org/0000-0002-7857-9783

Kyung-Woo Lee

https://orcid.org/0000-0002-3533-7979

Sang-Rak Lee

https://orcid.org/0000-0002-8905-0770

Competing interests

No potential conflict of interest relevant to this article was reported.

Funding sources

This work was supported by Korea Institute of Planning and Evaluation for Technology in Food, Agriculture, and

\section{INTRODUCTION}

At least $20 \%$ of chicken fresh-cut carcasses are transformed into mechanically deboned chicken meat (MDCM) [1]. Mechanically deboned chicken meat is high-calorie food material as $12 \mathrm{~kJ} / \mathrm{g}$ and contains plenty of unsaturated fatty acids including phospholipids [2]. However, as it contains approximately $12 \%$ crude fat, MDCM has low preservability due to rancidity [2,3] Therefore, most of MDCM has been used as substitutes in processed meats, such as meat emulsion, paste meat and chicken nuggets [1].

The companion animal food industry relies heavily on by-products of meat processing industries as sources of protein [4]. Therefore, the less-utilized MDCM could be reused as a value-added protein resource in the companion animal food industry through suitable procedures. The drawback of MDCM with respect to low preservation could be fully overcome by well-established fermentation technology. It is well known that the food fermentation has several advantages as follows: it preserves the raw ma- 
Forestry (IPET) through Agriculture and Life Industry Technology Development Program, funded by Ministry of Agriculture, Food and Rural Affairs (MAFRA) (118047-03-2CG000).

\section{Acknowledgements}

Not applicable.

Availability of data and material Upon reasonable request, the datasets of this study can be available from the corresponding author.

\section{Authors' contributions \\ Conceptualization: Lee SR. \\ Data curation: Lee E, Nam KT. \\ Formal analysis: Lee E, Nam KT, Lee KW. \\ Methodology: Nam KT, Lee SR. \\ Software: Lee KW. \\ Validation: Lee E, Lee KW, Lee SR. \\ Investigation: Lee E, Lee SR. \\ Writing - original draft: Lee E, Lee KW. \\ Writing - review \& editing: Lee E, Nam KT, Lee KW, Lee SR.}

Ethics approval and consent to participate All experiment procedures involving animals were conducted in accordance with the Animal Experimental Guidelines of the KULF Corp. (KULF-19-1). terials at low cost; enhances the nutritional quality by improving digestibility and protein quality; destroys toxic and undesirable components and harmful biota, protects against re-infection and adds antibacterial components; and improves the appearance, flavor and texture of foods [5,6]. In addition, allergic reactions induced by the increased use of proteins could be resolved by suitable fermentation [7]. With this background, the aim of this study was to evaluate the MDCM-based fermented snack for dogs.

\section{MATERIALS AND METHODS}

\section{Materials}

Chicken breast meat (CBM) and MDCM as main protein ingredients were obtained from a local chicken processing plant (Singgreen Food System, Iksan, Korea). Upon the receipt of CBM and MDCM, they were stored at $-20^{\circ} \mathrm{C}$ until use. The proximate analysis revealed the MDCM had $63.1 \%$ moisture, $53.2 \% \mathrm{CP}, 18.9 \% \mathrm{EE}$ and $2.7 \%$ ash on a DM basis. The CBM was composed of $73.5 \%$ moisture, $87.8 \% \mathrm{CP}, 4.6 \% \mathrm{EE}$ and $5.4 \%$ ash on a DM basis.

\section{Starter culture}

Pediococcus acidilactici (ATCC 8042) and P. pentosaceus (ATCC 8081) were obtained from the Korean Culture Centre of Microorganisms (KCCM, Seoul, Korea). Strains were enriched on MRS Agar (BD Difco, NJ, USA) at $37^{\circ} \mathrm{C}$ for $24 \mathrm{~h}$. Colonies were suspended with sterilized distilled water and used as a starter culture.

\section{Snack production}

The CBM and MDCM based meats were prepared for snack production. In brief, MDCM and CBM were thawed in refrigerator at $4{ }^{\circ} \mathrm{C}$, cut by $3 \times 3 \times 3 \mathrm{~cm}$ in size, and chopped with a meat grinder (M-12S, Hankook Fujee, Hwaseong, Korea) into small particles of $2.5 \mathrm{~mm}$ in diameter. The chopped raw meats were then mixed with sodium chloride, nitrate, nitrite, phosphate, cornstarch, and glucose. The mixtures were then divided into six equal batches of $1 \mathrm{~kg}$ each and wrapped with foils. Three of the batches were sterilized immediately at $121^{\circ} \mathrm{C}$ for $20 \mathrm{~min}$, kept in $-20^{\circ} \mathrm{C}$ until use and served as a non-fermented snack control. The other three batches were inoculated with the prepared starter culture to reach $10^{7} \mathrm{CFU} / \mathrm{g}$ meat mixtures and incubated in incubator (HB-101L, Hanbaek, Bucheon, Korea) at $37^{\circ} \mathrm{C}$ for $24 \mathrm{~h}$. The fermented batches were sterilized as described in the non-fermented control and kept in $-20^{\circ} \mathrm{C}$ until use. The ingredients and chemical compositions of chicken meat-based snacks were presented in Table 1.

\section{Snack sampling}

During a 24-hr fermentation, small portions $(\mathrm{n}=3)$ were sampled at $0,3,6,9,12,18$, and $24 \mathrm{~h}$ after the initiation of the incubation to measure the $\mathrm{pH}$ and the enumeration of lactic acid bacteria (LAB). In addition, the fermented and non-fermented snacks were analyzed for lactic acid, ammonia, moisture, crude protein, crude fat, crude ash, minerals, cholesterol, gross energy, amino acids, fatty acids, and in vitro pepsin digestibility.

\section{Preservability test}

To test preservability of the fermented or non-fermented snack food, approximately $200 \mathrm{~g}$ of the wet samples were weighed into $10 \mathrm{~cm}$ petri dishes and kept them with lid open on a laboratory at room temperature. Samples were taken at 0,1,2,3,5,7, and $14 \mathrm{~d}$ after exposure to the environment, and analyzed for the total bacteria, pathogenic bacteria, and LAB. 
Table 1. Formula and chemical composition of chicken meat based mixture

\begin{tabular}{|c|c|}
\hline Ingredients & $\%$ \\
\hline MDCM & 52.80 \\
\hline CBM & 35.20 \\
\hline Corn starch & 9.67 \\
\hline Glucose & 0.97 \\
\hline $\mathrm{NaCl}$ & 0.97 \\
\hline Phosphate & 0.29 \\
\hline $\mathrm{KNO}_{3}$ & 0.10 \\
\hline $\mathrm{NaNO}_{3}$ & 0.01 \\
\hline Total & 100.00 \\
\hline \multicolumn{2}{|l|}{ Calculated composition } \\
\hline Dry matter (\%) & 38.96 \\
\hline Crude protein (\% DM) & 21.11 \\
\hline Crude fat (\% DM) & 12.85 \\
\hline
\end{tabular}

MDCM, mechanically deboned chicken meat; CBM, chicken breast meat.

\section{Palatability trial}

Seven 2-year-old male adult Maltese with average body weight of $3.4 \mathrm{~kg}(\mathrm{SD}=0.35)$ were used for palatability trial. The dogs were randomly allocated to individual stainless cages of $75 \times 50 \times 60 \mathrm{~cm}$. A commercial feed (Natural Balance, Suwon, Korea) was used as the basal feed which contained $10 \%$ moisture, $25.6 \% \mathrm{CP}$, and $14.4 \% \mathrm{EE}$ on a DM basis. All dogs were initially fed to satiety with the basal diet and subsequently provided each dog with $50 \mathrm{~g}$ (approximately $1.5 \%$ of the individual body weight) of the fermented and non-fermented snacks. Palatability parameters monitored included smelling and eating behaviors, first choice, and eating time during 10 min after snack presentation. During $10 \mathrm{~min}$, smelling and eating behaviors on respective snacks were counted, and first choice was calculated as the percentage of dogs eaten the first snack sample. After 10 min of the test, the leftovers were measured to calculate food intake. Snacks were located in the same distance from each dog. The palatability test was repeated three times and averaged.

\section{Feeding trial}

Dogs that had been used for the palatability trial were initially provided with the commercial feed (Natural Balance, Suwon, Korea) every morning at the same time and the allowance was calculated based on the maintenance energy requirement [8]. Fermented and non-fermented snack foods were prepared as described earlier. The basal feed was gradually replaced with either fermented or non-fermented snack over the course of 7 days. After 7-d adaptation period, four Maltese dogs were provided with the non-fermented snack while three Maltese with fermented one during subsequent 12 days. Snacks (as-is basis) equivalent to $10 \%$ of the individual body weight were supplied ad libitum. The fecal and urine samples were collected during the last 5 days of the experimental period and pooled per dog. Urine samples were recorded per dog. All dogs were individually weighed at the initiation and the termination of the trial. All dogs had ad libitum access to drinking water using companion animal waterers. This experiment repeated twice with one-month interval. All experiment protocols were approved by the Animal Care Committee of KULF Corp. (KULF-19-1).

\section{$\mathrm{pH}$ measurement}

A $5-\mathrm{g}$ portion of the snack and fecal samples was homogenized with twice $(\mathrm{w} / \mathrm{w})$ the amount of distilled water, and measured by a $\mathrm{pH}$ meter (HI 120, Hanna instruments, RI, USA). 


\section{Chemical analysis}

The proximate composition of MDCM, CBM, non-fermented and fermented snacks, and fecal samples were analyzed by the methods of AOAC [9]. Gross energy was measured using Bomb calorimeter (C200H, IKA, Staufen, Germany). Cholesterol was quantified as described by An et al. [10] using IATRO SCAN (MK5, Iatron Laboratories, Tokyo, Japan) after extraction of the total lipid according to the methods of Folch et al. [11]. Lactic acid and ammonia were pre-treated by lactic acid kit (Megazyme, Wicklow, Ireland) and ammonia kit (Megazyme, Wicklow, Ireland), respectively, and then the concentrations were read at $340 \mathrm{~nm}$ by spectrophotometer (Synergy2, BioTek, VT, USA). To determine the fatty acid composition of the snack samples, total lipids were extracted according to the Folch et al. [11]. Then, the fat was saponified with $0.5 \mathrm{~N}$ methanolic sodium hydroxide and methylated with boronitrifloride-methanol complex according to the method of Metcalfe et al. [12]. The methylesters were separated and quantified by gas chromatography (HP5890, Agilent, CA, USA). Amino acid contents in the snack samples were quantified by amino acid analyzer (S433, Sykam, Eresing, Germany), following hydrolysis in $6 \mathrm{~N} \mathrm{HCl}$ for $24 \mathrm{~h}$ at $100^{\circ} \mathrm{C}$ as described elsewhere [9]. All the analysis was triplicated.

\section{In vitro digestibility assay}

Pepsin digestible nitrogen in the snack samples was determined according to the procedure of the AOAC [9] using $0.2 \%$ pepsin solution. The samples were defatted before analysis. The analysis was triplicated.

\section{Enumeration of bacteria}

Total bacteria, LAB, and pathogenic bacteria were measured using LB agar media (BD Difco, NJ, USA), MRS agar media (BD Difco, NJ, USA), and Orientation agar media (CHROMagar, Paris, France). Ready-to-use orientation agar medium is a non-selective medium for the isolation, direct identification, differentiation and enumeration of pathogens including Escherichia coli due to pathogen-specific colony color. Plates were incubated for $24 \mathrm{~h}$ at $37^{\circ} \mathrm{C}$, and colonies were counted and expressed as $\log _{10}$ transformed colony forming unit (CFU).

\section{Statistical analysis}

All data, if not stated otherwise, were analyzed by general linear model (GLM) of a SAS (SAS Institute, Cary, NC, 2002). Pearson's correlation between the $\mathrm{pH}$ and LAB in the fermented snack during fermentation process was also assessed. A $p<0.05$ was considered statistically significant.

\section{RESULTS AND DISCUSSION}

Fermentation characteristics and in vitro nutrient digestibility of the fermented snack Changes in $\mathrm{pH}$ and $\mathrm{LAB}$ population of the snack samples during fermentation process were presented in Fig. 1. The $\mathrm{pH}$ of the fermented snack decreased from 6.28 to 5.08 during the first $12 \mathrm{~h}$ of fermentation, and further declined to 4.76 at the end of fermentation. The initial LAB numbered $6.2 \times 10^{7} \mathrm{CFU} / \mathrm{g}$ and dramatically increased to $2.8 \times 10^{9} \mathrm{CFU} / \mathrm{g}$ by the time of $12 \mathrm{~h}$ fermentation. Based on this result, it is expected that the decrease in $\mathrm{pH}$ was secondary to the increased production of lactic acid contents by LAB during fermentation. The inverse relation $(r=-0.96)$ (Fig. 1) between $\mathrm{pH}$ and lactic acid seen in this study has been well documented [13,14].

Chemical compositions of fermented and non-fermented snack samples were shown in Table 2. Amino acid and fatty acid compositions were presented in Tables 3 and 4, respectively. Overall, fermented and non-fermented snack samples were not different in the analyzed nutrient compo- 
Table 2. Characteristics and chemical composition of fermented and non-fermented snack foods

\begin{tabular}{lcc}
\hline \multicolumn{1}{c}{ Items } & Non-fermented snack & Fermented snack \\
\hline $\mathrm{pH}$ & 6.28 & 4.76 \\
Lactic acid (mg/g) & 0.33 & 6.62 \\
Ammonia (g/L) & 0.18 & 0.46 \\
\hline Moisture (\%) & 65.1 & 64.5 \\
Crude protein (\%) & 13.9 & 14.1 \\
Ether extracts (\%) & 11.7 & 11.9 \\
Crude ash (\%) & 2.0 & 1.8 \\
Ca (\%) & 0.1 & 0.1 \\
$\mathrm{P}(\%)$ & 0.2 & 0.2 \\
$\mathrm{~K}(\%)$ & 0.3 & 0.3 \\
$\mathrm{Na}(\%)$ & 0.1 & 0.1 \\
$\mathrm{Mg}(\mathrm{ppm})$ & 202.4 & 191.5 \\
Fe (ppm) & 1.4 & 2.0 \\
$\mathrm{Cu}(\mathrm{ppm})$ & 1.2 & 1.2 \\
Zn (ppm) & 7.9 & 7.4 \\
Cholesterol $(\mathrm{mg} / 100 \mathrm{~g})$ & 42.7 & 46.5 \\
\hline Energy (kJ/g) & 9.5 & 10.2 \\
\hline
\end{tabular}

sitions. However, fermented vs. non-fermented snack contained higher lactic acid and ammonia concentration, but had lower $\mathrm{pH}$. It was shown that lactic acid concentrations increased from 2.5

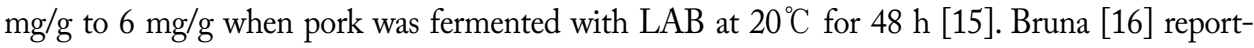
ed that ammonia contents increased approximately 200\% when the surface of sausage batch was sprayed with Penicillium camemberti and fermented at $22^{\circ} \mathrm{C}$ to $18^{\circ} \mathrm{C}$ for $72 \mathrm{~h} . \mathrm{Xu}$ [17] also reported that protein is decomposed to peptides and amino acids. Thus, the latter two studies explained the increased ammonia concentration in the fermented snack seen in this study.

In vitro pepsin digestibility in the fermented vs. non-fermented snacks was increased (Fig. 2), of which observation could provide the evidence that the fermentation can improve nutritive value. However, proximate analysis showed that fermentation did not affect the chemical compositions, amino acids and fatty acids.

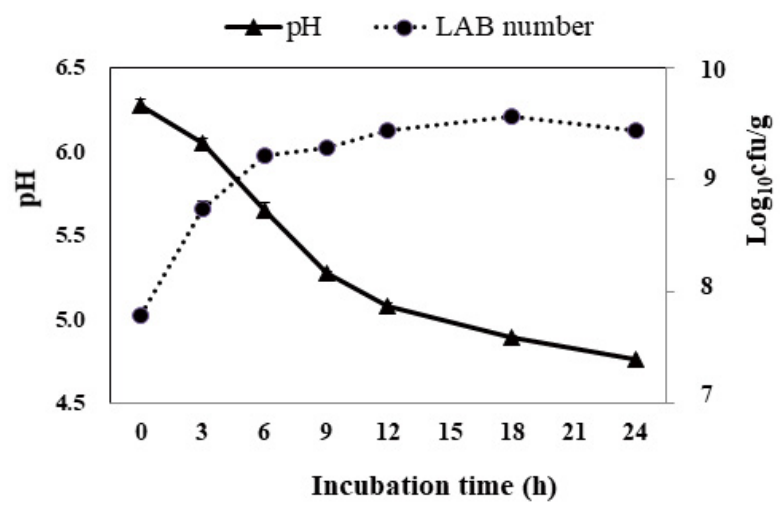

Fig. 1. Changes in $\mathrm{pH}$ and lactic acid bacteria (LAB) number of chicken meat snacks during $24 \mathrm{~h}$ fermentation. Data were represented as mean \pm standard error of 3 replications $(n=3)$.

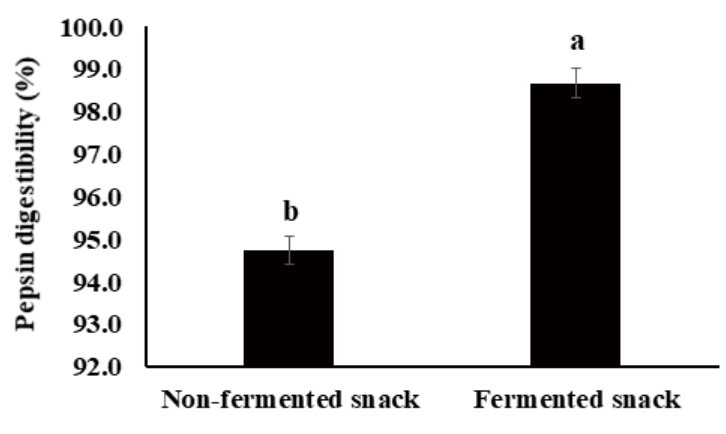

Fig. 2. In vitro pepsin digestibility of fermented and non-fermented snack food. Error bars indicate the standard error of three repeated measurements. ${ }^{\mathrm{ab}} p<0.05$. 
Table 3. Amino acid composition of fermented and non-fermented snacks ( $\mathrm{g} / 100 \mathrm{~g}$ of fresh sample)

\begin{tabular}{lcc}
\hline \multicolumn{1}{c}{ Amino acid } & Non-fermented snack & Fermented snack \\
\hline Asparagine & 1.34 & 1.39 \\
Threonine & 0.72 & 0.71 \\
Serine & 0.56 & 0.58 \\
Glutamine & 1.99 & 2.06 \\
Proline & 0.62 & 0.56 \\
Glycine & 0.74 & 0.75 \\
Alanine & 0.85 & 0.87 \\
Cysteine & 0.22 & 0.22 \\
Valine & 0.67 & 0.65 \\
Methionine & 0.00 & 0.00 \\
Isoleucine & 0.68 & 0.66 \\
Leucine & 1.13 & 1.19 \\
Tyrosine & 0.45 & 0.49 \\
Phenylalanine & 0.56 & 0.59 \\
Histidine & 0.81 & 0.81 \\
Lysine & 1.24 & 1.24 \\
Arginine & 0.89 & 0.89 \\
\hline Total & 13.47 & 13.66 \\
\hline
\end{tabular}

Table 4. Fatty acid composition of fermented and non-fermented snack food (\%)

\begin{tabular}{lrc}
\hline \multicolumn{1}{c}{ Fatty acid } & Non-fermented snack & Fermented snack \\
\hline Myristate $\left(\mathrm{C}_{14: 0}\right)$ & 0.64 & 0.66 \\
Myristoleate $\left(\mathrm{C}_{14: 1 n 5}\right)$ & 0.15 & 0.16 \\
Palmitate $\left(\mathrm{C}_{16: 0}\right)$ & 21.80 & 23.28 \\
Palmitoleate $\left(\mathrm{C}_{16: 1177}\right)$ & 6.90 & 6.51 \\
Oleate $\left(\mathrm{C}_{18: 1 \mathrm{nn}}\right)$ & 52.03 & 50.19 \\
Linoleate $\left(\mathrm{C}_{18: 2 n 6}\right)$ & 16.56 & 16.49 \\
Linolenate $\left(\mathrm{C}_{18: 3 n 3}\right)$ & 0.67 & 1.22 \\
11-Eicosenoate $\left(\mathrm{C}_{20: 1 n 9}\right)$ & 0.80 & 0.92 \\
Eicosatrienoate $\left(\mathrm{C}_{20: 3 n 3}\right)$ & 0.45 & 0.57 \\
\hline Total SFA & 22.44 & 23.93 \\
Total MUFA & 59.88 & 57.79 \\
Total $\omega-6$ & 16.56 & 16.49 \\
Total $\omega-3$ & 1.12 & 1.79 \\
Total $\omega-6 / \omega-3$ & 14.75 & 9.19 \\
Total PUFA & 2.06 & 2.18 \\
Total PUFA/SFA & 0.79 & 0.09 \\
\hline Total & 100.00 & 100.00 \\
\hline SFA, sat & &
\end{tabular}

SFA, saturated fatty acid; MUFA, monounsaturated fatty acid; PUFA, polyunsaturated fatty acid; $\omega$, Omega.

\section{Preservability of the fermented and non-fermented snacks}

Fig. 3 shows the preservability of the fermented and non-fermented snacks. The total bacteria of the non-fermented snacks started to appear on the first and the second day after exposure, respectively, and they increased linearly up to the 7 th day, reaching at $5.23 \log _{10} \mathrm{CFU} / \mathrm{g}$. Lactic acid bacteria grew slowly, and kept lower in number compared with the total and pathogenic bacteria. 


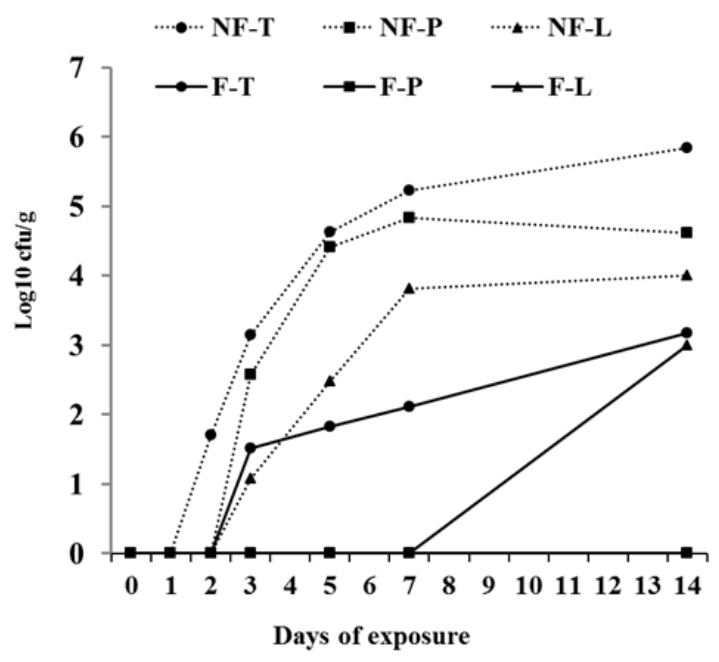

Fig. 3. Changes in bacterial number in fermented and non-fermented snack food exposed to environment at room temperature for $\mathbf{1 4}$ days. Total bacteria, lactic acid bacteria, and pathogenic bacteria were measured using LB agar media (BD Difco, NJ, USA), MRS agar media (BD Difco, NJ, USA), and Orientation agar media (CHROMagar, Paris, France). Colonies in Orientation agar plate were formed with nonfermented snack sample, but color-identifiable pathogen-specific colonies were not detected. NF-T, total bacteria in non-fermented snack sample; NF-P, pathogenic bacteria in non-fermented snack sample; NF-L, lactic acid bacteria in non-fermented sample; F-T, total bacteria in fermented snack sample; F-P, pathogenic bacteria in fermented snack sample; F-L, lactic acid bacteria in fermented sample.

On the other hand, total bacteria of the fermented snack reached to $3.18 \log _{10} \mathrm{CFU} / \mathrm{g}$ on the 14th day of exposure which was substantially lower than that of the non-fermented snack. Lactic acid bacteria appeared after the 7th day of exposure. Colonies in Orientation agar plate were formed with non-fermented snack sample, but color-identifiable pathogen-specific colonies were not detected. No single colony on Orientation agar plate was found with the fermented snack during the exposure. Based on this result, it is likely that organic acids, or bacteriocins, if any, present in the fermented snack could inhibit or delay the growth of bacteria. It is well documented that LAB could rapidly acidify the raw materials during fermentation, through the production of organic acids, mainly lactic acid and acetic acid, and also produce a variety of antimicrobial substances, which can consequently prevent the growth of the most hazardous food microorganisms [18].

\section{Palatability of the fermented and non-fermented snacks}

In palatability trial, dogs provided with the fermented vs. non-fermented snacks ate less, spent less time, and were reluctant to eat $(p>0.05)$ which was manifested by lowered frequency in smelling and eating (Table 5). The first choice of the non-fermented snack was significantly higher $(p<$ $0.05)$ than that of the fermented snack. Based on these results, it seems that the palatability of the fermented snack is low due to the strong odor of fermentation as indicated elsewhere [19]. Alternatively, low $\mathrm{pH}$ of the fermented snack per se may have reduced its palatability which was the case with pigs [20]. In any events, our study indicates that additional measures such as supplementation of natural flavors are needed to increase palatability of the fermented snack.

\section{Effect of feeding of the fermented and non-fermented snacks on fecal characteristics}

Dogs were fed with fermented or non-fermented snack foods for 12 days after 7-day transition period from the basal to the experimental food. During the trial, all dogs fed fermented or non-fermented snack food gained weight by $450 \mathrm{~g}$ and $340 \mathrm{~g}$ (Table 6). Dogs fed fermented vs. non-fer- 
Table 5. Palatability of fermented and non-fermented snack food in dogs

\begin{tabular}{lcc}
\hline \multicolumn{1}{c}{ Items } & Non-fermented snack & Fermented snack \\
\hline Smelling frequency (count/10 $\mathrm{min})$ & $10.00 \pm 2.02^{1)}$ & $6.67 \pm 0.88$ \\
First choice (\%) & $59.17 \pm 4.55$ & $40.83 \pm 4.55^{*}$ \\
Eating frequency (count/10 $\mathrm{min})$ & $3.67 \pm 0.71$ & $1.83 \pm 0.70$ \\
Eating time (sec/10 $\mathrm{min})$ & $78.17 \pm 16.46$ & $58.17 \pm 20.07$ \\
Food intake (g/10 $\mathrm{min})$ & $32.83 \pm 8.45$ & $20.67 \pm 7.80$ \\
\hline
\end{tabular}

${ }^{1)}$ Data are represented mean $\pm \mathrm{SE}$.

$p<0.05$.

Table 6. Fecal properties and urine production of dogs provided with fermented and non-fermented snack food

\begin{tabular}{lcc}
\hline \multicolumn{1}{c}{ Items } & Non-fermented snack & Fermented snack \\
\hline Number of animals & 4 & 3 \\
Feed intake (g DM/d/dog) & $115.81 \pm 12.84^{1)}$ & $146.57 \pm 2.53$ \\
Water intake (mL/d/dog) & $94.75 \pm 17.50$ & $74.33 \pm 19.72$ \\
Body weight & & \\
Initial (kg) & $3.25 \pm 0.34$ & $3.32 \pm 0.07$ \\
Final (kg) & $3.70 \pm 0.38$ & $3.66 \pm 0.25$ \\
Fecal ammonium (mg/g DM) & $163.27 \pm 11.92$ & $63.65 \pm 17.73^{* * *}$ \\
Fecal lactic acid (mg/g DM) & $2.56 \pm 0.15$ & $3.70 \pm 0.12^{* *}$ \\
Fecal pH & $6.86 \pm 0.17$ & $6.77 \pm 0.261$ \\
Urine (mL/d/dog) & $103.70 \pm 24.45$ & $118.00 \pm 21.81$ \\
\hline${ }^{11}$ Data are represented mean \pm SE. & &
\end{tabular}

mented snack ate more, but drank less, albeit that the difference was not statistically different. It is likely that low voluntary water intake in dogs fed fermented snack was secondary to the increase in involuntary water intake by consuming more moisture-rich snack. In this study, dogs preferred non-fermented vs. fermented snacks in the palatability trial while those offered fermented snack ate more compared with non-fermented snack-fed dogs in the 12-d-feeding trial. In addition, there was large variable in feed intake between individuals especially fed the non-fermented snack in the feeding trials. At this stage, a clear explanation is not readily available, but it seemed that individual dog differently responded to fermented snacks depending on the degree of satiety and/or feeding duration which needs to be answered.

Urine production was comparable between the treatment groups (Table 6). Ammonia concentration in feces was significantly lower in dogs fed fermented snack compared with those fed non-fermented snack. In contrast, fecal lactic acid content was significantly elevated in fermented snack-fed dogs compared with those fed non-fermented snack. However, elevated lactic acid in feces of the fermented vs. non-fermented snack did not affect fecal $\mathrm{pH}$. Decreased ammonia content and increased lactic acid in feces induced by dietary fermented snack may be in part secondary to balanced gut microbiota, i.e., LAB which could then inhibit pathogenic bacteria [21].

\section{CONCLUSION}

In this study, we manufactured Pediococcus spp.-fermented MDCM-based snack food for dogs. The nutritional compositions of the snack were not significantly altered by fermentation. However, in 
vitro pepsin digestibility was significantly increased by fermentation. Microbiological assay revealed that bacteria growth in fermented snack exposed to environment was delayed. In a palatability trial, dogs preferred non-fermented over fermented snack. In a feeding trial, fecal ammonia content was reduced, but fecal lactic acid content was increased in dogs fed fermented vs. non-fermented snack food. Collectively, the fermented MDCM-based snack for companion dogs can be used as a digestible snack with favorably long-term preservability. To our knowledge, this is the first report to show the possibility for utilizing the poultry by-product MDCM by fermentation process as a value-added snack for dogs, of which is considered of importance to companion animal industry.

\section{REFERENCES}

1. Negrao CC, Mizubuti IY, Morita MC, Colli C, Ida EI, Shimokomaki M. Biological evaluation of mechanically deboned chicken meat protein quality. Food Chem. 2005;90:579-83.

2. Dawson PL, Sheldon BW, Ball HR, Larick DK. Fatty acid composition of the neutral lipid and phospholipid fractions of mechanically deboned chicken meat. Poult Sci. 1990;69:1414-9.

3. Pikul J, Kummerow FA. Thiobarbituric acid reactive substance formation as affected by distribution of polyenoic fatty acids in individual phospholipids. J Agric Food Chem. 1991;39:451-7.

4. Morris JG. Pet food protein: current use and trends. Int News Fats Oils Relat Mater. 1990;1:206-8.

5. Stanton WR. Food fermentation in the tropics. In: Wood BJB, editor. Microbiology of fermented foods. London: Elsevier; 1985.p. 193-211.

6. Stanton C, Ross RP, Fitzgerald GF, Van Sinderen D. Fermented functional foods based on probiotics and their biogenic metabolites. Curr Opin Biotechnol. 2005;16:198-203.

7. El-Ghaish S, Ahmadova A, Hadji-Sfaxi I, El-Mecherfi KE, Bazukyan I, Choiset Y, et al. Potential use of lactic acid bacteria for reduction of allergenicity and for longer conservation of fermented foods. Trends Food Sci Technol. 2011;22:509-16.

8. Burger IH. Updated feeding recommendations for the canine diet. Waltham Focus. 1995;5:32.

9. AOAC [Association of Official Analytical Chemists] International. Official methods of analysis of AOAC International. 16th ed. Arlington, VA: AOAC International; 1995.

10. An BK, Nishiyama H, Tanaka K, Ohtani S, Iwata T, Tsutsumi K, et al. Dietary safflower phospholipid reduces liver lipids in laying hens. Poult Sci. 1997;76:689-95.

11. Folch J, Lees M, Sloane Stanley GH. A simple method for the isolation and purification of total lipides from animal tissues. J Biol Chem. 1957;226:497-509.

12. Metcalfe LD, Schmitz AA, Pelka JR. Rapid preparation of fatty acid esters from lipids for gas chromatographic analysis. Anal Chem. 1966;38:514-5.

13. Caplice E, Fitzgerald GF. Food fermentations: role of microorganisms in food production and preservation. Int J Food Microbiol. 1999;50:131-49.

14. Visessanguan W, Benjakul S, Riebroy S, Thepkasikul P. Changes in composition and functional properties of proteins and their contributions to Nham characteristics. Meat Sci. 2004;66:57988.

15. Minor-Perez H, Ponce-Alquicira E, Macias-Bravo S, Guerrero-Legarreta I. Changes in fatty acids and microbial populations of pork inoculated with two biopreservative strains. Meat Sci. 2004;66:793-800.

16. Bruna JM, Hierro EM, de la Hoz L, Mottram DS, Fernandez M, Ordonez JA. Changes in selected biochemical and sensory parameters as affected by the superficial inoculation of Penicillium camemberti on dry fermented sausages. Int J Food Microbiol. 2003;85:111-25.

17. Xu HQ, Wang WW, Jiang YS, Wang ZJ. Study on fermentation properties of lactic acid bacte- 
ria isolated from traditional fermented meat products. Sci Technol Food Ind. 2008;1:88-92.

18. Hu Y, Xia W, Ge C. Characterization of fermented silver carp sausages inoculated with mixed starter culture. LWT-Food Sci Technol. 2008;41:730-8.

19. Yang X, Chen H, Gao H, Li Z. Bioconversion of corn straw by coupling ensiling and solid-state fermentation. Biores Technol. 2001;78:277-80.

20. Brooks PH, Beal JD, Niven S. Liquid feeding of pigs: potential for reducing environmental impact and for improving productivity and food safety. Rec Adv Anim Nutr Aust. 2001;13:49-63.

21. Felix AP, Netto MVT, Murakami FY, de Brito CBM, de Oliveira SG, Maiorka A. Digestibility and fecal characteristics of dogs fed with Bacillus subtilis in diet. Cienc Rural. 2010;40:216973. 